Tohoku J. Exp. Med., 2004, 204, 209-213

\title{
Acute Phase Reactants in Allergic Airway Disease
}

\author{
Suna Büyüköztürk, Asli Akkor Gelincik, Sema Genç, ${ }^{1}$ Hikmet Koçak, ${ }^{1}$ Yildiz \\ Öneriyidogan, ${ }^{1}$ Sacide Erden, ${ }^{2}$ Murat Dal and Bahattin Çolakoglu \\ Department of Allergy, ${ }^{1}$ Department of Biochemistry, ${ }^{2}$ Department of Internal \\ Medicine, Istanbul University Faculty of Medicine, Istanbul, Turkey
}

Büyüköztürk, S., Gelincik, A.A., Genç, S., Koçak, H., Öneriyidogan, Y., Erden, S., Dal, M. and Çolakoglu, B. Acute Phase Reactants in Allergic Airway Disease. Tohoku J. Exp. Med., 2004, 204 (3), 209-213 — Acute phase reactants have been implicated for their involvement as proinflammatory molecules in various inflammatory diseases. However, little is known regarding their role in the allergic airway disease. The aim of the present study was to examine the blood concentrations of three acute-phase proteins, namely $\mathrm{C}$-reactive protein (CRP), serum amyloid A (SAA) and fibrinogen in patients with allergic rhinitis and asthma. Three study groups include: non-smoker allergic rhinitis $(n=50)$, non-smoker asthma $(n=20)$, and non-allergic, non-smoker healthy control subjects $(n=20)$. Patients who have had recent upper or lower respiratory tract infection and trauma, any rheumatological illnesses, malignancy or obesity were excluded. Blood samples were obtained from all the patients and control subjects and were analyzed for serum CRP, SAA and plasma fibrinogen. The mean CRP and fibrinogen values in the rhinitis and asthma groups were not significantly different when compared to the control group. However, the mean SAA levels of both groups were found to be significantly higher than those of the control group ( $p=0.002$ for rhinitis, $p=0.02$ for asthma). There was no significant correlation between the $\mathrm{FEV}_{1}$ values and the levels of the serum markers. This study demonstrates that acute phase reactant SAA rises in patients with allergic rhinitis and patients with asthma. We therefore suggest that SAA may have a role in the inflammatory airway disease. —— acute phase proteins; C-reactive protein; Serum amyloid A; fibrinogen; allergic rhinitis; asthma; inflammation (C) 2004 Tohoku University Medical Press

Several acute phase proteins have been mentioned to be substantially elevated during infection, trauma, surgery, burns, tissue infarction, various immunologically mediated conditions or cancer (Gabay and Kushner 1999). As their changes reflect the presence and intensity of in- flammation, they have been used as clinical markers in the diagnosis and management of some diseases. However, recent evidence has suggested that some of them might have proinflammatory properties (Blake and Ridker 2001). C-reactive protein (CRP), which is one of the most common-

Received May 21, 2004; revision accepted for publication September 14, 2004.

Address for reprints: Dr. Suna Büyüköztürk, Ataköy, 7-8. Kısım, Deniz 5/37, Istanbul, Turkey.

e-mail: sbuyuk@gediknet.com 
ly studied acute phase proteins, is shown to stimulate the release of inflammatory cytokines in monocytes. Another major acute-phase protein, serum amyloid A (SAA) is also demonstrated to cause adhesion and chemotaxis of phagocytic cells and lymphocytes in atherosclerotic plaques.

Asthma is considered as an inflammatory disease of airways. According to recent data, asthma and rhinitis are closely linked entities and they together define the unique inflammatory disorder, "United Airway Disease"(Passalacqua and Canonica 2002), or "Combined Allergic Rhinitis Asthma Syndrome." Some inflammatory markers, such as eosinophils, interleukin-5 (IL-5), eotaxin, eosinophilic cationic protein (ECP), and nitric oxide (NO) have been used to demonstrate the presence and persistance of airway inflammation.

In present study, we aimed to investigate the serum and plasma concentrations of three acute phase proteins, CRP, fibrinogen and SAA, in patients with allergic rhinitis and with asthma.

\section{Materials ANd Methods}

Among patients who referred to our out-patient clinic between September 2003 - December 2003, 50 consecutive patients with perennial allergic rhinitis and 20 with asthma have been chosen as the study groups. The diagnosis of rhinitis and asthma has been based on the history, physical examination, nasal smears, skin prick tests, paranasal sinus computerized tomographies (CT), pulmonary function tests with reversibility detection and chest X-rays. Exclusion criteria included a recent upper or lower respiratory tract infection and trauma, a rheumatological illness, malignancy and obesity. The patients whose sinus CT revealed prominent sinusitis, those who were on corticosteroid therapy and current smokers were also excluded. Twenty non-smoker healthy subjects with similar ages and female/male ratio consisted the control group.

After taking the informed consents of the patients, blood samples of $10 \mathrm{ml}$ have been obtained in appropriate conditions. All the asthmatic and allergic rhinitis patients were in asymptomatic stages when the blood samples were drawn. The samples were stored at $-70^{\circ} \mathrm{C}$ until the day on which they were analysed for the concentrations of three inflammatory markers.

Serum CRP concentrations were determined by microparticle enhanced turbidimetry with clinical chemistry analyzer Cobas Integra 400 (Roche Diagnostics GmbH, Manheim, Germany). Reference value by the clinical laboratory was $<5$ $\mathrm{mg} / 100 \mathrm{ml}$. Serum amyloid A concentration was measured using a Sandwich enzyme immunoassay kit (Biosource Int. Inc., Camarillo, CA, USA). Normal serum levels of SAA are $<10 \mu \mathrm{g} / \mathrm{ml}$, as suggested by Thomas (1982). Plasma fibrinogen was measured using coagulometric techniques (Behring Coagulation Timer). The levels of each inflammatory marker were compared between the study groups and the control group, using SPSS 10.0 version. In addition, the patients were compared in regard to disease severity as reflected by symptom levels and $\mathrm{FEV}_{1}$ values. Statistical analysis between the three groups was done by Kruskal-Wallis test. Pearson test was used for correlation analysis.

The study has been approved by the ethics committee of Istanbul University Faculty of Medicine.

\section{Results}

In the rhinitis and asthma groups, there were great differences in the CRP $(0.44-44.92 \mathrm{mg} / 100$ $\mathrm{ml})$ and SAA $(9.59-932 \mu \mathrm{g} / \mathrm{ml})$ concentrations of patients in contrast to fibrinogen, which was rather stable (Table 1). Although very high CRP levels were noticed in patients with rhinitis and asthma, the mean CRP and fibrinogen values in these groups were not significantly different when compared to the control group. However, the mean SAA levels of both groups were found to be significantly higher than that of the control group ( $p$ $=0.002, p=0.02$ respectively). As the allergic rhinitis and asthma have been regarded to be close entities by most authors, the two patient groups were combined as one and similar results were obtained when compared to the control group $(p=$ 
TABLE 1. The comparison of the characteristics of three groups ${ }^{\phi}$.

\begin{tabular}{|c|c|c|c|c|c|}
\hline & \multirow{2}{*}{$\begin{array}{l}\text { Allergic rhinitis } \\
\quad n=50\end{array}$} & \multirow{2}{*}{$\begin{array}{c}\text { Asthma } \\
n=20\end{array}$} & \multirow{2}{*}{$\begin{array}{c}\text { Control group } \\
n=20\end{array}$} & \multicolumn{2}{|c|}{ Significance } \\
\hline & & & & $p$ & ${ }^{* *} p$ \\
\hline Age & 18-43 (mean 32) & $18-49$ (mean 36) & $17-36($ mean 31$)$ & NS & NS \\
\hline Gender (F/M) & $36 / 14$ & $14 / 6$ & $15 / 7$ & & \\
\hline $\mathrm{FEV}_{1}(\% \text { predicted })^{\dagger}$ & $92( \pm 12.6)$ & $88( \pm 11.4)$ & $102( \pm 6.4)$ & NS & $<0.05$ \\
\hline CRP mg/100 ml & $4.2( \pm 8.8)$ & $3.06( \pm 2.7)$ & $3.3( \pm 6.4)$ & NS & NS \\
\hline Fibrinogen $\mathrm{mg} / \mathrm{ml}$ & $3.4( \pm 1.3)$ & $3.5( \pm 1.3)$ & $2.8( \pm 0.5)$ & NS & NS \\
\hline SAA $\mu \mathrm{g} / \mathrm{ml}$ & $71.7( \pm 158)$ & $66.3( \pm 74.7)$ & $19.5( \pm 1.8)$ & $p=0.0$ & $p=0.02$ \\
\hline
\end{tabular}

${ }^{*}$ Rhinitis vs. control.

${ }^{* *}$ Asthma vs. control.

${ }^{\dagger} \mathrm{FEV}_{1}=$ forced expiratory volume in 1 st second, expressed as $\%$ of predicted value.

${ }^{\S}$ The values are expressed as mean \pm S.D.

0.009). No significant correlation was found between the serum markers and $\mathrm{FEV}_{1}$ values.

\section{Discussion}

The results of the present study demonstrate that SAA concentrations are higher in patients with asthma and allergic rhinitis. This was not associated with any other inflammatory status of the patients and was not correlated with disease severity as reflected by $\mathrm{FEV}_{1}$ values. So far, we have been able to find only one study investigating the association of SAA with bronchial asthma. Jousilahti et al. (2002) have reported in their cross-sectional population-based study that SAA and fibrinogen were positively associated with asthma prevalence and they had concluded that systemic inflammation also existed besides the local inflammation in bronchial asthma. In two previously published population-based studies, high fibrinogen levels had been observed in asthmatic patients (Enright et al. 1996) and in chronic obstructive pulmonary disease (COPD) (Dahl et al. 2001).

Serum amyloid A has been mentioned to be an important acute phase reactant whose level in the blood increases in response to various insults (Urieli-Shoval et al. 2000). Its synthesis has been demonstrated to be regulated mainly by IL-1, TNF- $\alpha$, IL- 6 and glucocorticoids at both the transcriptional and post-transcriptional levels (Jensen and Whitehead 1998). Although its physiological role is not fully understood, it has been proposed by various studies that it involves in cholesterol metabolism and transport and in modulating the inflammatory response via both anti- and proinflammatory activities (Urieli-Shoval et al. 2000). SAA is implicated for its role in the pathogenesis of atherosclerotic plaques (Meek et al. 1994) and is detected in the brains of Alzheimer patients. Urieli et al. (1998) demonstrated SAA expression in histologically normal human tissues, mainly in epithelial and endothelial cells, and in lymphocytes. SAA has been demonstrated to be elevated in patients with lung cancer (Benson et al. 1986; Howard et al. 2003), cystic fibrosis (Smith et al. 1992), pulmonary tuberculosis (DeBeer et al. 1984) and sarcoidosis (Rothkrantz-Kos et al. 2003).

Allergic rhinitis and asthma are considered to be the two entities of the atopic syndrome (Braunstahl et al. 2003). Allergic rhinitis is also suggested to be related to systemic allergic manifestations. One of the proofs of this hypothesis is the systemic circulation of IgE antibodies, and another is peripheral eosinophilia (Alkis and Togias 2000). Different studies have indicated the involvement of the bone marrow in the development of eosinophilic inflammation of the airways. Denburg et al. (2000) have proposed that "the bone marrow is an ongoing source of chron- 
ic, systemic inflammation that seeds atopic tissues with cells that are capable of maturing into the effector cells of allergy".

Taken all together, we conclude that elevated SAA concentrations in patients with allergic airway disease may indicate the presence of systemic inflammation. The role of SAA in the airway inflammation still remains to be elucidated. Recently, Kallapur et al. (2003) demonstrated SAA 3 mRNA expression in the bronchial epithelial cells of the preterm lambs, due to endotoxininduced lung inflammation. Accordingly, it could be argued that SAA could be produced in the bronchial epithelial cells in response to airway inflammation in rhinitis and asthma. Obviously, the issue whether SAA can be useful for the followup of the allergic airway disease requires future investigations.

In conclusion, we found higher SAA concentrations in patients with allergic rhinitis and those with asthma compared to the control subjects. We suggest the involvement of SAA in development or persistence of these diseases.

\section{References}

Alkis, G. \& Togias, M.D. (2000) Systemic immunologic and inflammatory aspects of allergic rhinitis. J. Allergy Clin. Immunol., 106, S247-S250.

Benson, M.D., Eyanson, S. \& Fineberg, N.S. (1986) Serum amyloid A in carcinoma of the lung. Cancer, 57, 1783-1787.

Blake, G. \& Ridker, P.M. (2001) Novel clinical markers of vascular wall inflammation. Circ. Res., 89, 763-771.

Braunstahl, G.-J., Fokkens, F.J., Overbeek, S.E., KleinJan, A., Hoogsteden, H.C. \& Brins, J.-B. (2003) Mucosal and systemic inflammatory changes in allergic rhinitis and asthma: a comparison between upper and lower airways. Clin. Exp. Allergy., 33, 579-587.

Dahl, M., Tybjaerg-Hansen, A., Vestbo, J., Lange, P. \& Nordestgaard, B.G. (2001) Elevated plasma fibrinogen associated with reduced pulmonary function and increased risk of chronic obstructive pulmonary disease. Am. J. Respir. Crit. Care Med., 164, 1008-1011.

DeBeer, F.C., Nel, A.E., Gil, R.F., Donald, P.R. \& Strachan, A.F. (1984) Serum amyloid A protein and C-reactive protein levels in pulmonary tuberculosis: relationship to amyloidosis. Thorax, 39, 196-200.

Denburg, J.A., Sehmi, R., Saito, H., Pil-Seob, J., Inman, M.D. \& O’Byrne, P.M. (2000) Systemic aspects of allergic disease: Bone-marrow responses. J. Allergy. Clin. Immunol., 106, S242-250.

Enright, P., Ward, B.J., Tracy, R.P. \& Lasser, E.C. (1996) Asthma and its association with cardiovascular disease in elderly. J. Asthma, 33, 45-53.

Gabay, C. \& Kushner, I. (1999) Acute-phase proteins and other systemic responses to inflammation. New Eng. J. Med., 340, 448-454.

Howard, B.A., Wang, M.Z., Campa, M.S., Corro, C., Fitzgerald, M.C. \& Patz, E.F. (2003) Identification and validation of a potential lung cancer serum biomarker detected by matrix-assisted lazer desorption/ionvatron-time of flight spectra analysis. Proteomics, 3, 1720-1724.

Jensen, L.E. \& Whitehead, A.S. (1998) Regulation of serum amyloid A protein expression during the acute-phase response. Biochem. J., 334, 489-503.

Jousilahti, P., Salomaa, V., Hakala, K., Rasi, V., Vahtera, E. \& Palosuo, T. (2002) The association of sensitive systemic inflammation markers with bronchial asthma. Ann. Allergy. Asthma. Immunol., 89, 381-385.

Kallapur, S.G., Kramer, B.W., Moss, T.J., Newnham, J.P., Jobe, A.H., Ikegami, M. \& Bachurski, C.J. (2003) Maternal glucocorticoids increase endotoxin-induced lung inflammation in preterm lambs. Am. J. Physiol. Lung Cell Mol. Physiol., 284, L633-L632.

Meek, R.L., Urieli-Shoval, S. \& Benditt, E.P. (1994) Expression of apolipoprotein serum amyloid A mRNA in human atherosclerosis lesions and cultured vascular cells: implications for serum amyloid A function. Proc. Natl. Acad. Sci. USA, 91, 3186-3190.

Passalacqua, G. \& Canonica, G.W. (2002) Treating the allergic patient: think globally, treat globally. Allergy, 57, 876-883.

Rothkrantz-Kos, S., van Dieijen-Visser, M.P., Mulder, P.G. \& Drent, M. (2003) Potential usefulness of inflammatory markers to monitor respiratory functional impairment in sarcoidosis. Clin. Chem., 49, 1510-1517.

Smith, J.V., Colombo, J.L. \& McDonald, T.L. (1992) Comparison of serum amyloid A and C-reactive 
protein as indicators of lung inflammation in corticosteroid treated and non-corticosteroid treated cystic fibrosis patients. J. Clin. Lab. Anal., 6, 219-224.

Thomas, L. (1982) Roster diagnostisch wichliger proteine im plasma labor und Diagnose, 4th ed., edited by L. Thomas (Hrsg), Maburg Dis Med Verlagsgesellschaft, 748.

Urieli-Shoval, S., Cohen, P., Eisenberg, S. \& Matzner, Y. (1998) Widespread expression of serum amyloid A in histologically normal human tissues: predominant localization to the epithelium. $J$. Histochem. Cytochem., 46, 1377-1384.

Urieli-Shoval, S., Linke, R.P. \& Matzner, Y. (2000) Expression and function of serum amyloid $\mathrm{A}, \mathrm{a}$ major acute-phase protein, in normal and disease states. Curr. Opin. Hematol., 7, 64-69.

World Allergy Organization: Combined allergic rhinitis and asthma syndrome. http//www. worldallergy.org/professional/allergy_update/ caras/airwayssynapsis.html. Accessed. 